\title{
Geologi er gud
}

\section{Af GeologiskNyts webmaster geolog Steen} Laursen

"Som man råber i skoven, så får man svar", siger et gammelt ordsprog. Men hvis man nu råber til en, der er virkeligt intelligent og original, så kan man måske få et godt svar på et middelmådigt spørgsmål.

Internettet er en form for intelligens. Enorme mængder oplysninger er tilgængelig for en masse mennesker, som hele tiden sætter oplysningerne sammen på nye måder. Desuden tilføjer de oplysninger fra deres egne øjne og øren, så i dag har vi vel ikke adgang til en større viden og intelligens end selve internettet. Så det er egentlig bare at stille spørgsmålet om livet, geologien og alt det der og så se, hvad det er for noget med den geologi.

"Geologi er gud" giver ikke noget svar og dermed har internettet aflivet teorien om den uendelige abe. Hvis uendeligt mange aber hamrer løs på hver deres skrivemaskine i uendeligt lang tid, så vil en af dem før eller siden skrive Shakespeares samlede værker. Men hvis alverdens nørder endnu ikke har skrevet "geologi er gud", så skal der nok en meget lang uendelighed til for at skrive Shakespeare af.

\section{Et åbent spørgsmål}

Men uden gåseøjne giver Google en masse

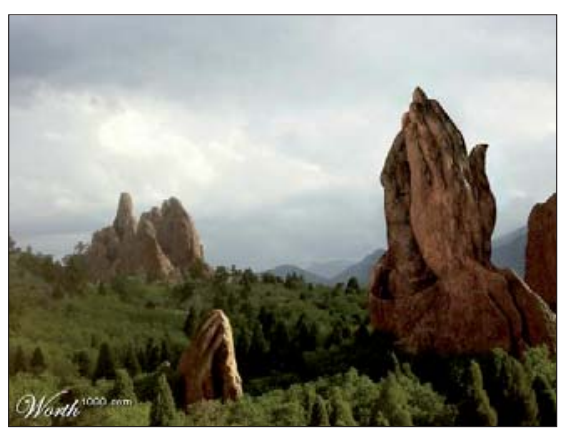

Kan man blande tro og geologi? (Fotomanipulation: www.worth1000.com)

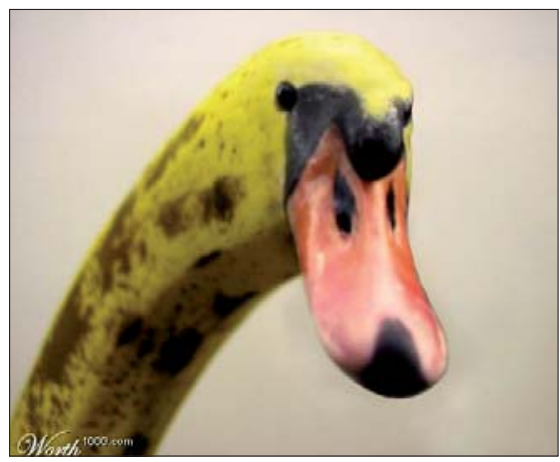

Er der en intelligens bag evolutionen? (Fotomanipulation: www.worth1000.com)

svar på spørgsmålet. Her er et svar fra internettet. Forskydninger i Jordens skorpe udløser jordskælv, vulkanudbrud og tsunamier, og der er ingen vilje eller hensigt indblandet i det, foreslår en præst. Gud har simpelthen lavet naturlovene, og nu kører de så deres egne veje.

Det her er en nytårsprædiken skrevet over jordskælvet og tsunamien i Sydøstasien i 2004, så Gud kan heldigvis også præsenteres $i$ et andet lys. Det lys skinner i dagens evangelium, og der fortsætter prædikenen så.

\section{Gud lavede geologien}

Men de fleste svar på dette spørgsmål handler om den verserende kamp mellem kristendom og videnskab. En af kreationisthjemmesiderne foreslår, at bibelens skabelsesberetning og geologien $i$ grunden er enige. For han mener, at både bibel og geologi viser, at alle landområderne har været samlet på et sted på Jorden, og at der dengang ikke var nogen store bjerge eller ørkener. Han mener for resten heller ikke, at der var forskel på temperaturen mellem nat og dag, der var ingen årstider og vigtigst af alt: Det regnede aldrig.

\section{Uvidenskabelig religion}

Næste hjemmeside er en af videnskabsfolkenes. Han hænger sig mere i tiderne i det her og synes ikke, der er tid nok i biblen til at få kontinenterne splittet op efter syndfloden, og den kan han i øvrigt ikke rigtigt få passet ind i sin kalender. Og så langer han lige en næve over bordet: Kreationisterne og andre intelligente designere er uvidenskabelige.

\section{Sagen på hovedet}

At spørge om "Gud er geologi" giver lige så lidt resultat som "Geologi er gud". Det store superintelligente internet har nok ikke set nogen grund til at blande de to ting sammen, og det er nok et meget godt svar. Svaret på spørgsmålet om livet, geologien og alt det der er måske bare, at geologi ikke er gud.

Guder og geologi har så forskellige grundlag, at de to ord end ikke kan optræde i den samme sætning. Religioner er jo kendetegnet ved, at intet skal bevises, og ingen kræver at det kan. Omvendt kræver naturvidenskaben netop, at alt skal bevises, og at hvert bevis kan gentages. Med de udgangspunkter kan de to ting ikke blandes, og deres tilhængere kan faktisk ikke engang diskutere.

Så til vores temmeligt middelmådige spørgsmål har det store, intelligente internet altså svaret, at hjemmesider, som blander gud og geologi sammen, ikke har svaret. $\mathrm{Og}$ nu er der øvrigt nogen, der skriver "Geologi er gud" på internettet. Det gør GeologiskNyt, for vi lægger denne artikel ud til alle de andre på vores hjemmeside. Gud ved, om det betyder, om vi har svaret?

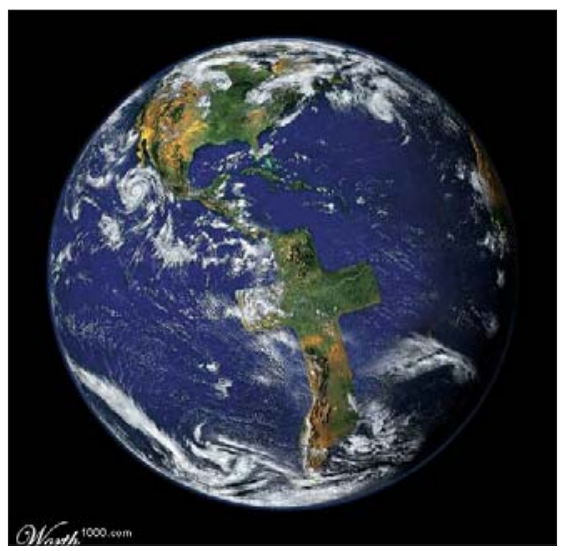

Skabte gud jorden? (Fotomanipulation: www.worth1000.com) 